\title{
Customer Satisfaction in Retail Banking Services in Nepal
}

\author{
Phul Prasad Subedi ${ }^{1}$
}

\begin{abstract}
This research mainly focuses on analysing the factors affecting customer satisfaction in retail banking in Nepal. The study adoptes descriptive and explorative research design to deal with the fundamental issues associated with various factors of customers' satisfaction and retail banking. The study is based on questionnaire survey of 200 customers of 10 different " $A$ " class financial institutions, i.e. commercial banks. Descriptive statistics, correlation coefficient and regression analysis have been applied to estimate the relationship between customer satisfaction as dependent variable and service quality variables as independent variables. The empirical evidences indicate that reliability, responsiveness, assurance and tangibles factors have positive and significant impact on customer satisfaction. It reveales that higher the level of responsiveness, reliability, assurance and tangibility higher would be the customer satisfaction.
\end{abstract}

Key Words: Customer Satisfaction, Reliability, Responsiveness, Assurance, Tangibility

\section{INTRODUCTION}

Customer satisfaction is the marketing term that measures how products or services supplied by a company meet or surpass a customer's expectations. In the competitive banking industry, customer's satisfaction is considered as the essence of success. Higher level of customer satisfaction enhances loyal customer base. Kumar et al., (2009) stated that high quality of service will result in high customer's satisfaction and increases customer loyalty. Hence, customer satisfaction is important because it provides marketers and business owners a metric that they can use to manage and improve their businesses (Adeoy \& Lawanson, 2012).

The customer satisfaction model proposed by Oliver (1980) explains that when the customers compare their perceptions of actual products/services performance with the expectations, then the feelings of satisfaction arises. Any discrepancies between

1. Mr. Subedi is Lecturer at Tribhuvan University, Faculty of Management, Central Department of Management. He can be reached at phulsubedi14@ gmail.com 
the expectations and the performance create disconfirmation. Further, Oliver (1980) identified three types of disconfirmation. Positive disconfirmation occurs when products/ services perform as per the expectations and the customers are highly satisfied. Negative disconfirmation occurs when products/services perform below their expectations which cause the customer highly dissatisfied. Zero disconfirmation occurs when products/ services perform equal to expectations. Thus, satisfaction is the customer's evaluation of a product or service in terms of whether that product or service has met its needs and expectations.

Service is a set of characteristics which aims to satisfy the clients and meet their needs (Beer, 2003 \& Walfried et al., 2000). Quality is such an important issue that it is considered a really significant concept in our real life. It is regarded as a strategic organizational weapon. And, the pressing need of developing service organizations and upgrading their services necessitates the measuring of service quality (Mohammad \& Alhamadani, 2011). Service quality has a significant impact on a bank's success and performance (Mouawad \& Kleiner, 1996). Service quality is particularly essential in the banking services context because it provides a high level of customer satisfaction, and hence it becomes a key to competitive advantage (Almossawi M., 2001). Banks have to care about the quality of their services since this quality is considered the essence or core of strategic competition (Mohamed \& Shirley, 2009). Parasuraman et al. (1985) defined service quality as a difference between customer expectation of service and customer's perceptions of the actual service.

There is fierce competition among banks to attract new customers and retain old ones. This has compelled banks to innovate new products and services, and adopt advanced technology. Banks have now realized the importance of service quality as it helps them to enhance the level of customer satisfaction which ultimately creates customer loyalty. Customer satisfaction, though a complex phenomenon (Kanji \& Moura, 2002), has been an integral component of the bank's core competence and performance (Kunst \& Lemmink, 2000). There is no consensus among authors regarding the definition and distinction between quality and satisfaction (Wisniewski, 2001). But for the purpose of this study, satisfaction is a "post consumption" experience which compares perceived quality with expected quality, whereas quality (service) refers to a global evaluation of a firm's service delivery system (Anderson, Fornell \& Lehmann, 1994).

The connection between service quality and customer satisfaction in service industry has been the subject of investigation (Caruana, 2002; Oh, 1999; Cronin et al., 2000; Parasuraman et al., 1985). However, the relevance of such issue is yet to be seen in case of least-developed economies like Nepal. In this context, this study examines customers' perception towards service quality and satisfaction in retail banking services in selected Nepalese commercial banks. More specifically, this study analyzes the relationship

2. All commercial banks in Nepal provide retail as well as corporate banking services. Since data on custumer satisfaction have been colleted only from retail service seekers, we used the term retail banking. 
between the measures of service quality (reliability, responsiveness, assurance and tangibility) and customer satisfaction in retail banking services ${ }^{2}$ in Nepal.

\section{LITERATURE REVIEW}

The construct of service quality and customer satisfaction have been the subject of debate in the service quality area for several years (Anderson \& Sullivan, 1993; Cronin \& Taylor, 1992 and Oliver, 1993). There is disagreement among the studies regarding the efficacy of the expectation-perception gap view of service quality as it is quite similar to the disconfirmation theory which is found in the consumer behavior studies (Gronroos, 1984). Some studies have suggested that performance-based technique should be used to measure the service quality (Cronin \& Taylor, 1994).

Caruana (2002) analyzed the effects of service quality and the mediating role of customer satisfaction on service loyalty. The study revealed positive and significant impact of tangibility, reliability and courtesy on customer satisfaction and customer loyalty. Similarly, the empirical evidences revealed negative and significant relationship between empathy and customer satisfaction and customer loyalty. Moreover, this study revealed customer satisfaction as the moderating variable in determining the effect of service quality on service loyalty.

Zafar et al. (2012) examined the fundamental constructs of quality of banking services, which influence customer satisfaction and determined the impact of customer satisfaction and customer loyalty in the context of banking relationships. The study found a positive and significance between various dimensions of service quality and customer satisfaction. Khan and Fasih (2014) assessed the satisfaction level of banking customers regarding quality of different services provided by their banks and their loyalty with the respective banks. The study showed that service quality and all its dimensions have significant and positive association with customer satisfaction and customer loyalty. Shanka (2012) examined the quality of service offered by private banks operating in Ethiopia. Results indicated positive correlation between the dimensions of service quality and customer satisfaction. Further, the results of the regression test showed that offering quality service have positive impact on overall customer satisfaction. The study shows that empathy and responsiveness play the most important role in customer satisfaction level followed by tangibility, assurance, and finally the bank reliability. The study also indicated that offering high level of service quality in order to increase customer satisfaction, which in turn leads to high level of customer commitment and loyalty.

Addo and Kwarteng (2012) assessed the determinants of customer satisfaction and the level of acceptability of services provided by private banks in Ghana, using the service quality dimensions. The results indicated that all the five dimension of service quality are significant predictors of customer satisfaction in retail banks in Ghana. In addition, the result showed that responsiveness and assurance are the most valued service qualities with highest loadings. The study shows that there is direct link between 
customer satisfaction and loyalty. Another study in Pakistan found out that different elements of service quality like tangibility, reliability, assurance, empathy, technology and responsiveness are important for bank customer's satisfaction (Ali \& Zhou, 2013). In addition, the result indicated that customer perception is highest on the assurance dimension of Islamic banks, and on the tangibles dimensional of conventional banks. However, customer perception is lowest in the technology and responsiveness dimension of Islamic bank. The study further indicated that overall perception about service quality is highest on Islamic banks.

Narteh and Kuada (2014) examined the determinants of customer satisfaction of retail bank services in Ghana. The empirical results indicated that relational, core, and tangible dimensions of service were positively associated with customer satisfaction in retail banks in Ghana. The study discussed the strategic implications of the findings for the management of customer satisfaction for retail banks operating in Ghana. The results show that Ghanaian bank customers attach significant importance to relational, core, and tangible dimensions of banking services offered by retail banks.

Cudjoe et al (2015) assessed the effect of service quality on customer satisfaction in the Ghanaian banking industry using Ghana Commercial Bank (GCB) as a study area. The expectations and perceptions of GCB customers were assessed under five dimensions of SERVQUAL. The study found out that, all the five dimensions contributed to quality of service delivery in GCB. Chiquvi and Chuma (2017) in their study determine the satisfaction level of customers in commercial banks in Botswana using the SERVQUAL model. The results showed that customers were not completely satisfied with the assurance, responsiveness, tangibles and reliability of commercial banks in Botswana.

There are only a few studies in this area in Nepalese context. They are reviewed in the following paragraph. Pradhananga (2014) assessed the relationship between service quality and customers satisfaction. The empirical evidence revealed that that the related dimensional service quality and the tangible dimensional service quality have a very low relationship with customer's satisfaction in Nepalese commercial banks. But core service quality has a significant impact on customer satisfaction. Koirala and Shrestha (2012) examined service quality and customer satisfaction with respect to the service quality dimensions in the Nepalese commercial banking sector. The empirical evidences suggested that Nepal Investment Bank was the most popular bank in commercial banks in Nepal. All the service quality dimensions (i.e., tangibles, reliability, responsiveness, assurance, and empathy) were found important for forming service quality and customer satisfaction of commercial banks in Nepal.

Gyawali and Kunwar (2014) conducted a study to explore customers' perceptions about banking service quality and their satisfaction taking attention over five service dimensions -responsiveness, tangibility, empathy, assurance and reliability using SERVPERF model. The analysis found that the overall perception of customers towards tangibility, reliability, responsiveness, assurance, and empathy was satisfactory. The study identified positive and significant relationship between customers' satisfaction and 
five service quality dimensions. Higher variability in overall SQ perception (satisfaction) is contributed by reliability, responsiveness, assurance, and empathy.

Maharjan (2014) in a study reported positive relationship between customers' satisfaction with service quality factors: assurance, technology, reliability, responsiveness, empathy, and tangibility. The study showed that service quality, customers' satisfaction, and customers' loyalty are positively related in commercial banks of Nepal. As per the study, reliability is the most important factor for service quality in commercial bank of Nepal and technology is the least important factor for service quality.

Shakya (2016) conducted study on the relationship between online banking system on customer satisfaction and performance of Nepalese commercial banks. Ease of use, usefulness, security, responsiveness and efficiency were taken as independent variables whereas return on assets, return on equity and customer satisfaction were dependent variables. Using regression model, the study revealed that customers' satisfaction, ease of use, usefulness, security, responsiveness and efficiency are positively related to return on assets and return on equity. Similarly, Upadhyay (2017) suggested that the overall performances of all the banks in terms of customer satisfaction have been satisfactory. Compared to government owned commercial banks performance of private banks have been satisfactory. Among different government banks the performance of RBB was found better than NBL and ADB.

\section{RESEARCH METHODOLOGY}

The Bank and Financial Instution Act 2006 has divided bank and financial institutions of Nepal in to four catagories. This study is confined with class "A" financial institutions i. e. commercial banks only. These banks are selected on the basis of their establishment date. The first ten banks are selected as a sample. In addition, non probability convenience sampling method was used to select the branches of the banks for questionnaire survey. Moreover, the study is based on primary questionnaire survey of 200 customers. The questionnaire used in this study is modified form of questionnaires used in previous studies (Premraj \& Sankaralingan, 2012), and (Parsuraman et al, 1988). The questionnaire is divided into three sections. Section, " $A$ " contains basic demographic information of the respondents. Section "B" includes multiple choice questions related with banks. And the last section " $C$ " comprises Likert Scale questions on service quality variables that affect customer satisfaction which ranges from 1 (strongly disagreed) to 5 (strongly agree). Further, in part "C" variables such as reliability, responsiveness, assurance and custormer satisction contain six statements in each of them, and tangibility conatains only four statements to measure responses. The data were collected from the customers who visited branches of sample banks in Kathmandu during the first hours of working days and agreed to fill in the questionnairers. The field survey was completed in first two weeks of January, 2019. Altogether 250 questionnaires were distributed and 200 questionnaires were returned in usable form with complete and clear information. Therefore, overall response rate was 80 percentage. The data obtained from the 
questionnaire survey were analyzed using SPSS Version 22. The reliability of the scales used for the service quality and customer satisfaction variables in the questionnaire were evaluated using Cronbach's alpha. The overall Cronbach's alpha for the four aspects and four components of service quality was 0.813 .

The regression model used for the analysis, along with the descriptions of variables, is as below:

$$
C S=\alpha+\beta_{1} R E L+\beta_{2} R E S+\beta_{3} A S S+\beta_{4} T A N+e
$$

\section{Customer Satisfaction (CS)}

Satisfaction is a "post consumption" experience which compares perceived quality with expected quality. Following (Halstead et al., 1994), customer satisfaction has been defined as the overall attitude of the customer towards a particular organization.

\section{Reliability (REL)}

Reliability refers to sincerity and interest of bank and its employees in solving customer's problem and providing them right services at the first time (Parsuraman et al., 1985). The attributes of the reliability are providing on-time services, having error-free record, fulfilling the promises made, providing complete and correct information to the customers (Bahia \& Nantel, 2000).

\section{Responsiveness (RES)}

Responsiveness determines the employees' level of involvement and concerns for customers requiring assistance. Responsiveness also involves understanding the need and wants of customers. It also includes convenient operating hours, individual attention given to customers by the staff, attention to problems faced by customers and customer's safety in their transactions (Kumar et al., 2009 and Othman \& Owen, 2001).

\section{Assurance (ASS)}

Assurance plays important role to ensure high quality service in banks. Assurance can be given to customers by showing kindness, courtesy, admiration and neat appearance of the employees. It also includes providing customer's financial advices, comfortable environment of the banks and providing customers the information which is easily understandable and accessible (Kumar et al., 2009; Othman \& Owen, 2001 and Bahia \& Nantel, 2000).

\section{Tangibility (TAN)}

Tangibility refers to the physical appearance of the things and facilities provided to customers. For instance, response of bank employees, equipment they use and material associated with services which are visually appealing to customers (Guo \& Hair, 2008). Employees and customers are usually influenced by tangibility of service in physiological, emotional and cognitive ways (Aslam et al., 2011). 


\section{RESULT AND DISCUSSION}

This section presents the data analysis and discussions on the results thereon. It begins with the description of respondents' profile in terms of their gender, age group, qualification, and profession. Then, it presents perceptions of respondents on different statements of service quality dimensions - realiability, responsiveness, assurance and tangiability; and customer satisfaction. Finally, it reports the extent of relationship between variables; and explainatory power of each independent variable on dependent variable with the help of Pearson's correlation and regression analysis.

\section{Brief Description of Respondents' Profile}

Out of the total respondents, the proportion of male and female was almost equal - $51 \%$ were male and $49 \%$ female. Similarly, the age group of the respondents was categorized into five groups i.e. below 20,21 to 29,30 to 39,40 to 49 and above 50 years. The majority of the respondents $(43.5 \%)$ fell under the age group of $20-29$ years followed by $30-39,40-49$, above 50 and below 20 years. The respondents were offered six options regarding the profession. The response indicated that the majority of respondents were salaried person (53\%) in different sectors followed by students, others, business person and housewife respectively. On the basis of the academic qualification respondents were categorized as Intermediate or below, Bachelor's degree, Master's degree, MPhil/ $\mathrm{PhD}$, Professional degree. The responses indicated that the majority of the customer had completed master's degree (43\%) followed by bachelor's degree, intermediate and below, professional degree (2\%) and M. Phil/ PhD respectively.

\section{Perception Analysis}

\section{Perception on service quality dimensions}

The responses on the four service quality dimensions of Nepalese commercial banks havebeen presented in tabular form depicting the number of responses in terms of frequency $(F)$, percentage $(\%)$ and mean value of the five point Likert scale (1 as strongly disagreed, 2 as disagreed, 3 as neither agree nor disagreed, 4 as agree and 5 as strongly agree) and which is calculated on basis of the respondents' opinion on given statements.

\section{Perception on reliability}

Table 1 presents responses on various statements reflecting reliability dimension of service quality of sample banks. The mean of the statements about reliability ranges from a minimum value of 3.30 to the maximum value of 3.99 . Among them, the statement "Customer feel safe in their transaction" scored highest mean value of 3.99 with lowest standard deviation (0.842). It means that most respondnts agree that they feel safe while doing transactions in the banks. The statement "the bank advertisement and promotional message reflect reality of their service" scored the lowest mean value of 3.30. The mean score on all statements reflecting reliability is greater than 3 , which indicates that customers of the sample banks are satisfied with the reliability dimension 
52 I PYC Nepal Journal of Management, August 2019, Vol. XII, No. 1

of service quality of the sample banks. But at the same time, it should be noted that a significant number of respondents have ticked on the "neither agree nor disagree" option in most statements meaning that banks' small effort can enhance reliability score further.

Table 1

Perceptions on Reliability

\begin{tabular}{lccccccccc}
\hline Statements & & 1 & 2 & 3 & 4 & 5 & Total & Mean & S. D. \\
\hline $\begin{array}{l}\text { Bank provide the service at the time they promise } \\
\text { to do }\end{array}$ & $\mathrm{F}$ & 16 & 24 & 66 & 62 & 32 & 200 & 3.35 & 1.129 \\
$\begin{array}{l}\text { Employees are sincerely interested in solving } \\
\text { customer's problem }\end{array}$ & $\mathrm{F}$ & 9 & 34 & 42 & 94 & 21 & 200 & 3.42 & 1.034 \\
$\begin{array}{l}\text { Bank keep their record sincerely } \\
\text { Customer feel safe in their transaction }\end{array}$ & $\mathrm{F}$ & 8 & 12 & 22 & 107 & 51 & 200 & 3.91 & 0.98 \\
$\begin{array}{l}\text { Bank advertisement and promotional message } \\
\text { reflect reality }\end{array}$ & $\mathrm{F}$ & - & 16 & 24 & 107 & 53 & 200 & 3.99 & 0.842 \\
Services are carried out right at the first time & $\mathrm{F}$ & 15 & 22 & 74 & 67 & 22 & 200 & 3.30 & 1.050 \\
\hline
\end{tabular}

Perception on responsiveness

Table 2 depicts the responses on various statements reflecting the responsiveness dimension of service quality of the sample banks. The mean values of all these six statements lies in the range of 3.20 to 3.67. Among them, the most significant observation of the respondents on the reliability is "Providing correct response to the customers" with mean value of 3.67 whereas the least scored statement is "Employees of the bank are never too busy to respond to customer's request" with mean value of 3.20. The overall mean value of responses is greater than 3 which indicated that customers' have positive perception on responsiveness of the sample banks.

Table 2

Perception on Responsiveness

\begin{tabular}{llllllllll}
\hline Statements & & 1 & 2 & 3 & 4 & 5 & Total & Mean & S. D. \\
\hline Bank provide the prompt service to the customer & $\mathrm{F}$ & 3 & 36 & 45 & 89 & 27 & 200 & 3.50 & 0.987 \\
Employees of the bank are willing to help & $\mathrm{F}$ & 5 & 26 & 47 & 94 & 28 & 200 & 3.57 & 0.969 \\
Customers & & & & & & & & \\
Providing correct response to the customers & $\mathrm{F}$ & 3 & 20 & 49 & 96 & 32 & 200 & 3.67 & 0.914 \\
Bank provides special care to special customers & $\mathrm{F}$ & 5 & 25 & 47 & 79 & 44 & 200 & 3.66 & 1.034 \\
Bank provide financial advice & $\mathrm{F}$ & 17 & 25 & 59 & 78 & 21 & 200 & 3.31 & 1.090 \\
$\begin{array}{l}\text { Employees of the bank are never too busy to } \\
\text { respond to customer request }\end{array}$ & $\mathrm{F}$ & 18 & 38 & 53 & 68 & 23 & 200 & 3.20 & 1.147 \\
\hline
\end{tabular}

\section{Perception on assurance}

Table 3 represents the opinions of the sampled customers on the assurance of the selected banks. The mean values of all these four statements range from 3.44 to 3.59 which shows that there is not a big difference between the highest and lowest mean 
value. However, there is consistency in responses of the respondents on the specified Likert scale items. The highest mean is 3.59 and lowest mean is 3.44 . Thus, in conclusion respondents have positive perception on the assurance of the sample banks.

Table 3

Perception on Assurance

\begin{tabular}{llllllllll}
\hline Statements & & 1 & 2 & 3 & 4 & 5 & Total & Mean & S. D. \\
\hline Clients of the banks can trust employees of the bank & $\mathrm{F}$ & - & 27 & 67 & 87 & 19 & 200 & 3.49 & 0.845 \\
Employees of the banks are polite & $\mathrm{F}$ & 5 & 20 & 52 & 93 & 10 & 200 & 3.59 & 0.915 \\
Inform exactly when services will be performed & $\mathrm{F}$ & & 24 & 73 & 93 & 10 & 200 & 3.44 & 0.768 \\
Employees are fast and efficient in service delivery & $\mathrm{F}$ & 5 & 26 & 64 & 81 & 24 & 200 & 3.47 & 0.950 \\
\hline
\end{tabular}

Perception on Tangibility

Table 4 shows perception of the customers on tangibility of surveyed banks. The mean values of all these six statements range from 3.31 to 3.78 , that shows there is consistency in responses of the respondents on the specified Likert scale items statements. The lowest mean is 3.31 for the statement "Bank material associated with service are clear, readable and understandable" on the other hand, the highest mean is 3.78 for the statement "Employees are neat and look professional in appearances."

Table 4

Perception on Tangibility

\begin{tabular}{lccccccccc}
\hline Statements & & 1 & 2 & 3 & 4 & 5 & Total & Mean & S. D. \\
\hline Banks physical facilities are visually appealing & $\mathrm{F}$ & 8 & 25 & 55 & 100 & 12 & 200 & 3.41 & 0.926 \\
Bank has modern looking equipment & $\mathrm{F}$ & - & 26 & 60 & 99 & 15 & 200 & 3.51 & 0.814 \\
Employees are neat and look professional in & $\mathrm{F}$ & 3 & 10 & 37 & 129 & 21 & 200 & 3.78 & 0.76 \\
appearances & $\mathrm{F}$ & 11 & 23 & 41 & 96 & 29 & 200 & 3.55 & 0.859 \\
Bank's location and layout is appropriate & $\mathrm{F}$ & 5 & 29 & 73 & 85 & 8 & 200 & 3.31 & 0.859 \\
Materials associated with services (such as & $\mathrm{F}$ & 6 & 18 & 42 & 101 & 33 & 200 & 3.68 & 0.954 \\
pamphlets or statements) are visually appealing & Bank has convenient branch location & & & & & & &
\end{tabular}

Perception on satisfaction in retail banking

Table 5 presents the perception of customers' satisfaction on the quality of services of customers on retail banking of sampled banks. The mean of customer satisfaction ranges from a minimum value of 3.03 to the maximum value of 3.37 . Among them, the most favoured observations of the respondents regarding the customer is "Performance of bank is more than my expectation" with mean value of 3.37 whereas the least favored observation is "I am satisfied with the services provided by bank" with mean value of 3.03. In a nutshell, the average mean value of responses on satisfaction is greater than three which indicate that the customers of sample banks satisfied by the services offered by them. The response of the responses is represented in the table 5 . 
54 I PYC Nepal Journal of Management, August 2019, Vol. XII, No. 1

Table 5

Perception on Customer Satisfaction

\begin{tabular}{|c|c|c|c|c|c|c|c|c|c|}
\hline Statements & & 1 & 2 & 3 & 4 & 5 & Total & Mean & S.D. \\
\hline I am satisfied with the services provided by bank. & $\mathrm{F}$ & 18 & 54 & 46 & 68 & 14 & 200 & 3.03 & 1.12 \\
\hline Bank's forms and slips are easy to understand and fill. & $\mathrm{F}$ & 4 & 46 & 67 & 70 & 13 & 200 & 3.21 & 0.938 \\
\hline Performance of bank is more than my expectation. & $\mathrm{F}$ & 9 & 27 & 68 & 73 & 23 & 200 & 3.37 & 1.004 \\
\hline $\begin{array}{l}\text { Bank provides clear and understandable bank } \\
\text { statement. }\end{array}$ & $\mathrm{F}$ & 22 & 30 & 66 & 66 & 16 & 200 & 3.12 & 1.110 \\
\hline $\begin{array}{l}\text { I am cheerful and happy to have my account in this } \\
\text { bank. }\end{array}$ & $\mathrm{F}$ & 7 & 35 & 68 & 71 & 19 & 200 & 3.30 & 0.982 \\
\hline $\begin{array}{l}\text { I can apply for cheque book at any branch where I find } \\
\text { convenient. }\end{array}$ & $F$ & 13 & 38 & 59 & 73 & 17 & 200 & 3.21 & 1.056 \\
\hline
\end{tabular}

\section{Correlation Analysis}

Pearson's correlation has been used to angibi the relationship between the dependent variable customer satisfaction (CS) and the independent variables reliability $(R E L)$, responsiveness (RES), assurance (ASS) and tangibility (TAN). The Pearson's correlation coefficients have been presented in Table 6.

Table 6

Correlation Coefficients

\begin{tabular}{lcccccccc}
\hline & Mean & Std. Deviation & P Value & CS & REL & RES & ASS & TAN \\
\hline CS & 3.21 & 0.84531 & & 1 & & & & \\
REL & 3.57 & 0.76183 & 0 & $0.689^{* *}$ & 1 & & & \\
RES & 3.48 & 0.72122 & 0 & $0.701^{* *}$ & $0.750^{* *}$ & 1 & & \\
ASS & 3.49 & 0.69793 & 0 & $0.754^{* *}$ & $0.710^{* *}$ & $0.793^{* *}$ & 1 & \\
TAN & 3.54 & 0.67157 & 0 & $0.601^{* *}$ & $0.628^{* *}$ & $0.529^{* *}$ & $0.617^{* *}$ & 1 \\
\hline
\end{tabular}

Notes. ${ }^{* *}$ Correlation is significant at the 0.01 level (2-tailed).

The empirical evidences suggested that there is strong positive and significant correlation between customer satisfaction and assurance, responsiveness, reliability and tangibility. The results suggested that the higher level of customer satisfaction can be achieved by improving service quality variables such as reliability, assurance, responsiveness and tangibility in banks.

\section{Regression Analysis}

Regression analysis has been carried on to find out the extent of effect of each variable which had significant relationship with customer satisfaction. The summary of regression result of the study has been presented in the table 7.

The empirical results showed that value of $R$ square is 0.637 and $F$ value is 84.935 with the $p$ value 0.000 which is less than alpha $(0.000<0.05)$. These values indicated that the model is significant, and the independent variables namely reliability, responsiveness, 
assurance and angibility are able to explain variance in customer satisfaction significantly. Specifically, the model explains $63.70 \%$ of variability in customer satisfaction.

Table 7

Regression results

\begin{tabular}{|c|c|c|c|c|c|}
\hline \multicolumn{2}{|c|}{ Unstandardized Coefficients } & \multicolumn{4}{|l|}{$\begin{array}{l}\text { Standardized } \\
\text { Coefficients }\end{array}$} \\
\hline$\underline{B}$ & Std. Error & Beta & $\mathrm{T}$ & Sig. & \\
\hline (Constant) & -.567 & .217 & & -2.614 & .010 \\
\hline REL & .209 & .081 & .189 & 2.596 & .010 \\
\hline RES & .196 & .093 & .167 & 2.112 & .036 \\
\hline ASS & .478 & .094 & .395 & 5.077 & .000 \\
\hline TAN & .190 & .074 & .151 & 2.569 & .011 \\
\hline F statistics & 84.935 & & R Square & .635 & \\
\hline$P$ value & 0.00 & & Adjusted R Square & .628 & \\
\hline
\end{tabular}

All independent variables are statistically significant at $5 \%$ level of significance. This finding is consistent with Shanka (2012), Gyawali and Kunwar (2014), Caruana (2002) but contrasts with Chiguvi, Muchingami and Chuma (2017) among others.

\section{CONCLUSION}

The study indicated that reliability, responsiveness, assurance and tangibles factors have positive and significant impact on customer satisfaction. It revealed that higher the responsiveness, reliability, assurance and tangible factors would lead to higher level of customer satisfaction. The findings of this study are in consistent with Shanka (2012), Gyawali and Kunwar (2014), Caruana (2002) but contrasts with Chiguvi, Muchingami, and Chuma (2017) among others. Moreover, commercial banks in Nepal can enhance the level of customer satisfaction by focusing their attention on those variables and ultimately contribute to customers' loyalty towards the bank.

\section{Scope for Future Reseach}

This study has tried to cover the issues related with the customer satisfaction in retail banking services of Nepalese commercial banks. This paper contributed value in the existing literature in the field of service quality and customer satisfaction. Future researchers can include other financial intuitions and increase no of commercial banks so that the findings can be properly generalized in Nepalese banking industry. This study confined with in Kathmandu valley but future studies can cover the different parts of the country. In addition, future researcher can also include other important variables which may have significant impact on customer satisfaction such as empathy, communication, security, technology, convenience, internet banking etc. 
56 I PYC Nepal Journal of Management, August 2019, Vol. XII, No. 1

\section{REFERENCES}

Addo, A., \& Kwarteng, K. (2012). Customer's satisfaction in retail banking services: a study of selected private banks in Ghana. International Journal of Social Science Tomorrow, 1(6), 1-9.

Adeoye, B., \& Lawanson, O. (2012). Customer satisfaction and its implications for bank performance in Nigeria. British Journal of Arts and Social Sciences, 5(1), 13-29.

Ali, F., \& Zhou, Y. (2013). Assessment of the perceive service quality comparison of Islamic and conventional banks at Pakistan. International Journal of Innovation and Business Strategy, 2(1), 45-58.

Almossawi, M. (2001). Bank selection criteria employed by college student in Bahrain: An empirical analysis. International Journal of Bank Marketing, 19(3), 115-125.

Anderson, E. W., \& Fornell, C. and Lehmann, D. R. (1994). Customer satisfaction, market share and profitability: Findings from Sweden. Journal of Marketing, 58(3), 53-70.

Anderson, E. W., \& Sullivan, M. W. (1993). The antecedents and consequences of customer satisfaction for firms. Marketing Science, 12(2), 125-143.

Aslam, H. D., Khan, M. \& Tanveer, A. (2011). Perceive barriers towards adoption of internet banking among non-metropolitan internet users of Pakistan. International Business and Economics Research Journal, 10(4), 45-55.

Bahia, K., \& Nantel, J. (2000). A reliability and valid measurement scale for the perceived service quality of banks. International Journal of Bank Marketing,18(2), 84-91.

Beer, M. (2003). Why Total Quality. Why total quality management programs do not persist the role of management quality and implication for leading a TQM transformation. Decision Science, 34(4), 624-642.

Caruana, A. (2002). Service quality: The effects of service quality and the mediating role of customer satisfaction. European Journal of Marketing, 36(7), 811-828.

Chiguvi, D., Muchingami, L., \& Chuma, R. (2017). A study on customer satisfaction in commercial banks in Botswana, International Journal of Innovative Research in Science, Engineering and Technology, 6(4), 5112-5119.

Cronin, J., \& Taylor, S. A. (1992). Measuring service quality: A re-examination and extension. Journal of Marketing, 56(3), 55-68.

Cudjoe, A. G., Anim, P. A. \& Nyanyofio, J. N. (2015). Service quality and customer satisfaction in the Ghanaian banking industry (A case of Ghana Commercial Bank). European Journal of Business and Management, 7(3), 123-140.

Gronroos, C. (1984). A service quality model and its marketing implications, European Journal of Marketing, 18(4), 35-44.

Gyawali, S., \& Kunwar, N. (2014). Customer Satisfaction over Service Quality Dimensions: Exploring SERVPERF in Private Banks of Butwal. The KIC Journal of Management and Economic Review, 1(2), 14-27.

Guo, X., Duff, A. \& Hair, M. (2008) Service quality measurement in the Chinese corporate banking market. International Journal of Bank Marketing, 26(5), 305-27.

Kanji, G. K. \& Moura, P. E. (2002). Kanji's business scorecard - quality assurance and total quality management. Total Quality Management and Business Excellence. 13(1). 13-27.

Khan, M. M., \& Fasih, M. (2014). Impact of service quality on customer satisfaction and customer loyalty: Evidence from banking sector. Pakistan Journal of Commerce and Social Sciences, 8(2), 331-354. 
Koirala, K. D., \& Shrestha, S. K. (2012). Measuring service quality and customer satisfaction: Empirical evidence from Nepalese commercial banking sector undertakings. Management Dynamics, 16(1), 10-20.

Kumar, M., Kee, F. T. \& Manshor, A. (2009). Determining the relative importance of critical factors in delivering service quality of banks: An application of dominance analysis in SERVQUAL model. Managing Service Quality, 19(2), 211-228.

Kunst, P., \& Lemmink, J. (2000). Quality management and business performance in hospitals: A search for success parameters. Total Quality Management, 11(8), 1123-1133.

Maharjan, M. (2014). Service quality, customers' loyalty in commercial banks of Nepal. Nepalese Journal of Management, 1(1), 100-106.

Mohammed, H. \& Shirley, L. (2009). Customer perception on service quality in retail banking in Middle East: the case of Qatar. International Journal of Islamic and Middle Eastern Finance and Management, 2(4), 338-350.

Mohammad, S. A. A. \& Alhamadani, M. Y. S. (2011), Service quality perspectives and customer satisfaction in commercial banks working in Jordan. Middle Eastern Finance and Economics, $14,61-72$.

Mouawad, M., \& Kleiner, B. (1996). New developments in customer service training. Managing Service Quality, 6(2), 49-56.

Narteh, B., \& Kuada, J. (2014). Customer satisfaction with retail banking services in Ghana. Thunderbird International Business Review, 56(4), 353-371.

Oh, H. (1999). Service quality, customer satisfaction, and customer value: A holistic perspective. Hospitality Management, 18, 67-82.

Oliver, R. L. (1980). A cognitive model of the antecedents and consequences of satisfaction decisions. Journal of Marketing Research, 17(4), 460.

Oliver, R. L. (1993). Cognitive, affective, and attribute bases of the satisfaction response. Journal of Consumer Research, 20(1), 418-430.

Othman, A., \& Owen, L. (2001). Developing an instrument to measure customer service quality $\mathrm{SQ}$ in Islamic banking. International Journal of Islamic Finance Service, 30(1), 1-26.

Parasuraman, A., Zeithaml, V. \& Berry, L. (1985). A conceptual model of service quality and its implications for future research. Journal of Marketing, 49, 41-50.

Pradhananga, S. (2014). Impact of service quality on customer satisfaction in Nepalese commercial banks. The KIC Journal of Management and Economic Review, 1(2), 52-60.

Premraj, H., \& Sankaralingam, N. (2012). Customer satisfaction in Indian retail banking: A study with reference to Chennai. Indian Journal of Commerce and Management Studies, 3(1), 3841.

Shanka, M. S. (2012). Bank service quality, customer satisfaction and loyalty in Ethiopian banking sector. Journal of Business Administration and Management Sciences Research, 1(1), 1-9.

Shakya, R. (2016). Impact of service quality dimensions on customer satisfaction and customer loyalty in Nepalese commercial banks. Nepalese Journal of Business, 1(1), 43-54.

Upadhyay, J. P. (2017). Customers' satisfaction in commercial bank. International Journal of Science, Technology and Management, 6(3), 341-347.

Walfried, L. M., Chris, M. \& Robert, D. W. (2000). Service quality perspective and satisfaction in private banking. Journal of Service Marketing, 14(3), 244-271 
58 I PYC Nepal Journal of Management, August 2019, Vol. XII, No. 1

Wisniewski, M. (2001). Using servqual to assess customer satisfaction with public sector services. Managing Service Quality, 11(6), 380-388.

Zafar, M., Zafar, S., Asif, A., Hunjra, A. I., \& Ahmad, M. H. (2012). Service quality, customer satisfaction and loyalty: an empirical analysis of banking sector in Pakistan. Information Management and Business Review, 4(3), 159-167. 